\title{
Balaton környéki biotópokból (Tihany, Külső-Somogy) származó Granaria frumentum (DRAPARNAUD, 1801) héjmorfológiájának klímafüggése (Gastropoda: Chondrinidae)
}

\author{
1DOMOKOS TAMÁS, ${ }^{2}$ SÓLYMOS PÉTER és ${ }^{3}$ KOVÁCS CSONGORNÉ
}

\author{
${ }^{1} \mathrm{H}-5600$ Békéscsaba, Rábay utca 11., e-mail: tamasdomokos@freemail.hu \\ ²Alberta Biodiversity Monitoring Institute, University of Alberta T6G 2E9 Alberta, Canada., e-mail: solymos@ualberta.ca \\ ${ }^{3} \mathrm{H}-7400$ Kaposvár, Zárda utca 2. Nagyboldogasszony Iskolaközpont., e-mail: domokosevi@gmail.com
}

Tisztelettel ROTARIDESZ MIHÁLY (Gyulafehérvár, 1893 - Budapest, 1950) születésének 120. évfordulójára

\begin{abstract}
Dомокоs T., Sólymos, P. \& Kovács, Cs-né: The influence of climate on the shell morphometry of Granaria frumentum (DRAPARNAUD, 1801) in the environs of the Balaton (Gastropoda: Chondrinidae).

Abstract: We present morphometric results for eight populations (680 specimens) collected fom diffrent Granaria frumentum habitats from Tihany and Külsö-Somogy. Macroclimatic features of different sampling areas are unchanged, but in spite of the fact we found differences in some instances between size characteristics and distribution curves of the sampled populations. By our opinion these deviatons were genereted by microclimatic differences of the different habitats. Therefore morhometry based climate reconstruction requires more research and validation.
\end{abstract}

Keywords: Hungary, landsnails, mollusca, shell morphometry, macroclimate, morpho-thermometer methods

\section{Bevezetés}

1. A szárazföldi molluszkák minimális mozgékonysága, kvázi kötött életmódja megköveteli élőhelyük mikroklíma változásaihoz való maximális alkalmazkodásukat. A szárazföldi csigák aktív, E1 létállapotuk (Domokos 1995, 2002) kivételével a talaj (redzina, mezőségi stb.) felszínén, azt borító detrituszban, a takaró növényzet szubsztrátumában tartózkodnak. Ennek hőmérséklete - adott makroklíma esetén - jelentősen eltérhet a talaj tulajdonságaitól, a talajfelszín morfológiájától, kitettségétől/ lejtőszögétől; a szubsztrátum víz- és páratartalmától függően.

Domokos et al. 2004 akáccal és tölggyel borított somosi holtmederben, (Sarkad, Sarkad-Remeteierdő), Ny-K irányú transzekt mentén tanulmányozták a talajfelszín morfológiájában meglévő különbségek mikroklímatológiai, malakocönológiai hatását (2002. aug.16/17.). A beárnyékolt, 3,5 m relatív mélységü meder két oldalának legmagasabb és legmélyebb pontja között a hömérséklet napi átlagában $0,5-1,0^{\circ} \mathrm{C}$, a relatív páratartalmában pedig $6,5 \%$ különbséget észleltek. A nagynak nem nevezhető differencia ellenére a malakocönózisban, ökológiai fajcsoportokban, a malakocönózis szerkezeti karakterisztikáiban (összegyedszám, élő egyedek \%-a, abundancia, dominancia) jól érzékelhető eltérések mutatkoztak.

A kitettség következtében meglévő hőmérsékleti különbségek - az elöbb említett $0,5-1,0{ }^{\circ} \mathrm{C}$-nál - lényegesen jelentősebb is lehetnek. Erre korábban már DöVÉNYI et al. 1977 és NAGY 1992 is rámutatott.
DöVÉnYı et al. 1977 a Szabadkígyósi puszta (Békés megye: Szabadkígyós) legnagyobb relatív magasságú (6,5 m) kunhalmán, az 1976-os nyári napforduló idején, tanulmányozta többek között a mikroklíma hömérséklet elemét is. A kunhalom északi és déli oldalán mért talajfelszíni maximális hőmérséklete között $5,8^{\circ} \mathrm{C}, 20 \mathrm{~cm}$-es magasságban mért léghőmérséklet maximumai között csupán $2,3^{\circ} \mathrm{C}$ eltérés mutatkozott a déli oldal javára.

NAGY 1992 a Bükkben végzett mikroklíma mérései is igen tanulságosak. A közel 50 m-es szintkülönbségủ Szentléleki völgy (Miskolc, Hámor) talpa és felső pereme között a napi (1983. júl. 14.) átlaghőmérséklet $-2 \mathrm{~cm}$-re a talaj felszínétől - északi kitettségü oldalon $22,4^{\circ} \mathrm{C}$, a délin pedig $24,0^{\circ} \mathrm{C}$ volt, ami azt jelenti, hogy a különböző expozíciójú lejtők átlaghőmérséklete között $1,6^{\circ} \mathrm{C}$ különbség adódott.

Az Ásottfa-tető (Kisgyőr) különböző kitettségű ( $D$, É), a talajfelszíntől különböző magasságban (2, 5, 20 $\mathrm{cm}$ ) egy napon (1988. aug. 31.) keresztül mérte a mikroklímát. A déli és északi kitettségű oldalon $20-5-2 \mathrm{~cm}$ magasságban, az átlaghőmérsékletekben 1,3-2,0-3,1 ${ }^{\circ} \mathrm{C}$, a $20 \mathrm{~cm}$ magasságban mért maximumokban pedig $0,9^{\circ} \mathrm{C}$ különbség adódott.

NAGY \& Sólymos (2002) az Aggteleki-karszt egyik $10 \mathrm{~m}$ mély gyepes (Polygalo /major/ - Brachipodietum pinnati) töbrében végzett mikroklíma vizsgálatokat 1998-1999-ben. Az északi és déli kitettségű oldalak napi átlaghömérséklete között nem találtak eltérést $2 \mathrm{~m}$ magasságban. A napi átlaghőmérséklet különbsége 2,4 ${ }^{\circ} \mathrm{C}$-nak adódott közvetlenül a talaj felszíne felett $(2 \mathrm{~cm})$. Az Aggteleki-karszt Alsó-hegyi erdősült (juhar- és bükkelegyes cseres-tölgyes) 10-30 m relatív mélységű töbreiben a csigaegyüttesek összetételét és abundancia viszonyát jelentősen befolyásolta a töbörmorfológia és a kitettség (Kemencei et al. 2014).

A fenti méröhelyeken kapott adatok összevetése sok buktatót rejt magában, hiszen többek között földrajzi helyzetükben (Északi-Középhegység, DK-Alföld), morfológiájukban (kunhalom, hegytető, völgy, meder), kitettségükben (É-D, K-Ny), makroklímájukban, fedettségükben (gyep, lágyszárú, erdö, töbör) és a mért adatok kiértékelésének, feldolgozásának mikéntjében is különböznek egymástól. A 6,5 m magasságú szabadkígyósi kunhalom és kisgyőri Ásottfa-tető É-i és $D$-i oldalán $20 \mathrm{~cm}$ magasságban mért hőmérsékleti maximumok rangsorában a kunhalom $1,4^{\circ} \mathrm{C}$-al meg- 
előzi az Ásottfa-tetőt. Ez plauzibilis, ha figyelembe vesszük a délkelet-magyarországi pusztában fekvő gyeppel borított kunhalom klimatikus adottságait.

A 50 m szintkülönbségü Szentléleki völgy és a 3,5 m mély sarkadi holtmeder klímaviszonyainak öszszevetése elsőre erőltetettnek tünik, hiszen a völgy nagyságrenddel mélyebb, hőmérsékletprofilja pedig aszimmetrikus, szemben a meder megközelítően szimmetrikus voltával. Mindenképpen arra lehet számítani, hogy a 15-ször mélyebb völgyben - még azonos makro- / lokális klíma esetén is - nagyobb lesz a fenti és lenti hömérséklet különbség. NAGY 1992 és DomoKos et al. 2004 szerint - a $2 \mathrm{~cm}$ szintben illetve a talaj felszínén mért hőmérsékletet azonosnak véve (fraus pia!) - a völgy két oldalán $1,0-1,0^{\circ} \mathrm{C}$-nak, a meder oldalain pedig $0,5-1,0^{\circ} \mathrm{C}$-nak adódik a különbség. Tekintettel arra, hogy a hőmérsékleti gradiens függőleges komponense a völgyben $0,02^{\circ} \mathrm{C} / \mathrm{m}$, a mederben viszont 0,14 és $0,28^{\circ} \mathrm{C}$ között változik, a csigaegyüttesek karakterisztikái a mederben lesznek változatosabbak.

A klíma különböző puhatestű fajok héjmorfológiájára, cönológiai viszonyaira kifejtett hatását hazánkban LAIS 1925, 1926 nyomán - korábban RotARIDESz 1927, 1931, Agócsy 1961, 1962, 1966, FüKÖH 1980 is vizsgálta. Az idő előrehaladtával a szerzők klímaelemek szempontjából kvalitatív szemlélete kvantitatívra váltott, majd a kutatások klíma-rekonstrukció irányába fordultak (DoMOKоS 1982-83, 1987, 1992, 2001, 2002, Doмокоs \& FÜKÖH 1984, SÜMEGI 1989, 1996, SólyMOS 1996, Sólymos \& NAGY 1997, Sólymos \& Domokos 1999, Sólymos \& SÜMEGI 1999, Sólymos et al. 2002, BÁBA \& Domokos 2002).

Az abiotikus faktorok közül a klimatikus tényezők két eleme (hőmérséklet, páratartalom) és a Granaria frumentum házának mért és számított paraméterei (magasság, szélesség, nyúltság) közötti kapcsolatot először Doмokos \& FüKÖH 1984, 1986 tanulmányozta. Az Upponyi-szoros déli (Kereszteskő) és északi (Símakő) kitettségű szikláin élő Granaria frumentumok házainak magasság és szélesség eloszlásában, gyakorisági görbéinek lefutásában hőmérséklettől és páratartalomtól függő különbséget mutattak ki, a házak nyúltságában (magasság/szélesség mérőszáma) viszont nem tapasztaltak eltérést. A július első felére (1978. július 1-14.) számított középhőmérséklet emelkedésével, a relatív páratartalom átlagok csökkenésével a különböző kitettségü helyeken nőtt a ház magasságának és szélességének a módusza. Sejtésük szerint az optimum $21^{\circ} \mathrm{C}$-on, a minimum pessimum 19 ${ }^{\circ} \mathrm{C}$ alatt, a maximum pessimum pedig $23^{\circ} \mathrm{C}$ alatt volt.

Néhány évvel később SüMEG 1989 a Granaria frumentum optimumát $21,5 \pm 1{ }^{\circ} \mathrm{C}$-ban, aktivitási tartományát pedig $17-26^{\circ} \mathrm{C}$-ban adta meg. Tehát Sümegi megközelítően hasonló optimumot, de $5^{\circ} \mathrm{C}$-kal tágabb vitális zónát tételez fel. Ezen nem csodálkozunk, ha figyelembe vesszük, hogy Sümegi a faj egész areájára vonatkozó értéket ad meg.

Sólymos 1996 a csigaegyüttesek cönológiai és ökológiai viszonyait a Szársomlyó (Villányi hegység) déli oldalának kilenc biotópjában vizsgálta. Nyílt, átmeneti jellegü és zárt területeken karakteres különbséget mutatott ki az egyes puhatestü fajok előfordulásában, abundanciájában, implicite egyes területek mikroklímájában.

A következő lépésként a déli kitettségű mintahelyek mikroklímáját vizsgálva SólYmos \& NAGY 1997 megállapították, hogy az élőhely 0 és $2 \mathrm{~m}$ magasságban mért mikroklímája hatást gyakorol a molluszkák cönózisára.

Később Sólymos \& Domokos 1999 irodalmi makroklímaadatok birtokában (MAROsı \& SOMOGYI eds. 1990, PÉcsı et al. 1989) vizsgálta a Granaria frumentum morfológiai plaszticitását. Megállapították, - és ezzel alátámasztották a korábbi eredményeket (Doмокоs \& FüKÖH 1984,1986) - a házak mérete a júliusi középhőmérséklettel pozitív, az évi csapadékmennyiséggel pedig negatív kapcsolatban áll.

A következő években - Domokos 1985 munkáját követve -, Sólymos \& SümEgl 1999, Sólymos et al. 2002 a korábbi eredmények paleoklimatológiai és paleoökológiai alkalmazásának lehetőségeiröl is beszámolt.

2. Az 1970-es évek végén a balatoni Fekete-part környékének malakofaunáját Domokos Tamás és Kovács Gyula tanulmányozta (Domokos \& KovÁcs 1982). Feltủnt a két kutatónak, hogy a Balatont különböző távolságban kísérő magaspart egyes szakaszai és a távolabbi dombok löszgyepei jelentős Granaria frumentum populációkat rejtenek. 1980 és 1987 között - az előbbi tapasztalatok birtokában - Domokos későbbi vizsgálatok céljára, egyeléssel jelentős példányszámú sokfogú magcsiga anyagot gyűjtött, amelyet a Munkácsy Mihály Múzeum (Békéscsaba) puhatestü-gyűjteményében helyezett el. E minták héjmorfológiai vizsgálatát annak idején el is végezte, de a nyert statisztikai eredmények kiértékelésére, közlésére a mai napig nem került sort.

Mivel a dél-dunántúli Szársomlyón 1996-ban gyűjtött csigaegyüttes anyagon már történtek biogeográfiai (Sólymos 1996), a domináns Granaria frumentum fajon pedig héjmorfológiai vizsgálatok (Sólymos \& Doмокоs 1999), kézenfekvőnek tűnt egy tihanyi és hét somogyi dombsági biotópból (Balatonszárszó, Szólád, Kötcse) származó korábbi minta további feldolgozása, és a nyert paraméterek szársomlyói mintával történő öszszehasonlítása.

Természetesen a vizsgálatok nem zárulnak le véglegesen, hiszen a Granaria frumentum viszonylag gyakori és nagy abundanciájú előfordulásai lehetővé teszik a további gyűjtések adatsorainak a feldolgozását is (1. ábra). („Napos, füves lankákon, a földön, a fü töve körül, azonkívül sziklákon, régi kőfalakon és kövek alatt rendesen tömegesen található...Nálunk gyakori, Az Alföldön és a Dunántúlon általánosan elterjedtnek mondható..." - írja Soós 1943 klasszikus munkájában.) 


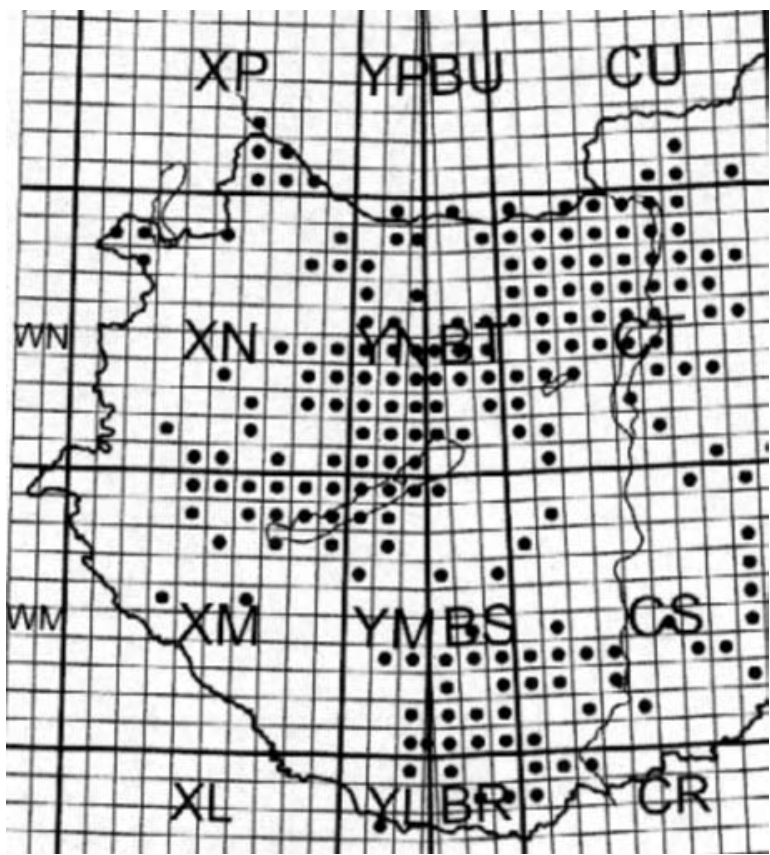

1. ábra: Granaria frumentum előfordulások a Dunántúlon $10 \mathrm{~km} \times 10 \mathrm{~km}$-es UTM hálózatos megjelenítésben (PINTÉR \& SUARA 2004)

Fig. 1.: Occurrence of the Granaria frumentum in Transdanubian part of the Hungary in $10 \mathrm{~km} \times 10 \mathrm{~km}$ UTM grid system (PINTÉR \& SUARA 2004)

\section{Anyag és módszer}

A vizsgálatok alapját - a bevezetésben már említett - 8 db 1980-es évekből származó adatsor (összesen 680 példány) képezte:

1. YN 10: Tihany, Ciprián-forrás közeli ligetes rész, É-i kitettség, 1982.08. 21. (100)

2. YM 19: Balatonszárszó, Kültelek u., magaspart, akácos, lágyszárú, 1980.10.17. (80)

3. YM 19: Balatonszárszó, Kültelek u., magaspart, akácos, lágyszárú, 1985.06. 27. (100)

4. YM 19: Balatonszárszó, Kültelek u. magaspart, akácos, lágyszárú, 1987. (100)

5. YM 19: Balatonszárszó, Tábor u., homokbánya, ÉNY-i expozíciójú löszgyep, 1987.08.30. (100)

6. YM 18: Balatonszárszó, Almahegy, NY-i kitettségü homokfal, löszgyep, 1983.08. 27.(50)

7. YM 18: Szólád, ÉNY-i kitettségü domboldal, bebokrosodó löszgyep, 1983.07.02.(50)

8. YM 18: Kötcse, Ny-i kitettségű domboldal, bebokrosodó löszgyep, 1981.08.18. (100)

Zárójelben feltüntettük a gyüjtött egyedek számának azon részét, amelyet statisztikai számításokhoz felhasználtunk, azaz megadjuk a mintaelemszámot is.

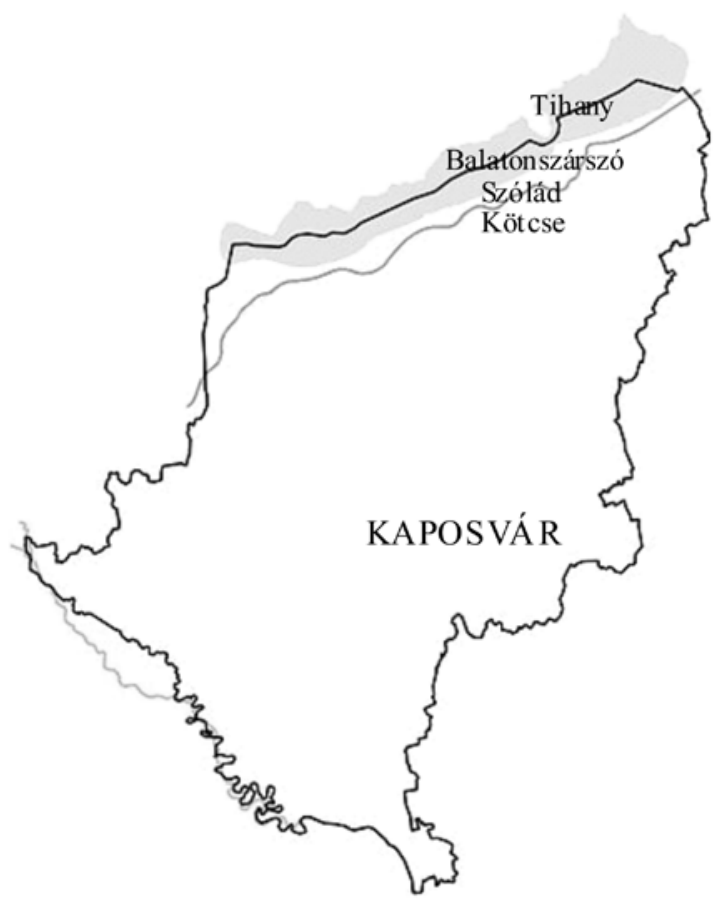

2. ábra: A gyüjtőhelyek vázlatos elhelyezkedése Somogy megyében

Fig.2.: The topographic sketch map of the sampling site in Somogy county

Ezek a gyűjtőhelyek Tihanyban és Külső-Somogyban (2. ábra), PINTÉR \& SUARA 2004 puhatestű katalógusában megtalálható - YN 10, YM 19, YM 18 jelü 10 $\mathrm{km} \times 10 \mathrm{~km}$-es UTM kvadrátban fekszenek. Az 1. és a 2-5., valamint a 6 . és 8 . gyűjtőhely között megközelítően $10-10 \mathrm{~km}$ a távolság.

A minták makroklíma szempontjából egységesen a $11-12{ }^{\circ} \mathrm{C}$ évi, $20-21{ }^{\circ} \mathrm{C}$ júliusi átlaghőmérsékletü; 650-700 mm évi, 40-60 mm júliusi csapadékmenynyiségü területről származnak (AmBRózY et al. 2003), és térben - Tihany kivételével - megközelítően É-D irányt követik. (Tihany Balatonszárszótól ÉÉK-i irányba esik.) Az előbbi klímaelemek adatait az „Időjárás havijelentés Magyarországról” OMSZ kiadvány 1974 és 1985 közötti időszakára számolva: $10,5^{\circ} \mathrm{C}$ évi, 20,7 ${ }^{\circ} \mathrm{C}$ júliusi átlaghőmérséklet; $610 \mathrm{~mm}$ évi, $60 \mathrm{~mm}$ júliusi csapadékmennyiség adódik.

Minden minta esetében, itt is felmerült a gyűjtött példányok létállapotának kérdése (Domokos 1995). A tihanyi és a hét külső-somogyi mintasorban csupán $10 \%$ körüli volt az élő (E1 és E2 létállapotú) egyedek száma. A többi példányhoz rendelhető exisztálási idő megállapítása igen bizonytalan, annál is inkább, mert az is előfordulhat, hogy az élő állat elveszti házának periosztrákum rétegét, és első pillanatra fosszilisnek is tünhet. A Granaria frumentum háza viszonylag vastag falú, ezért nehezen pusztul, ráadásul a löszös talajok jelentős mésztartalma fékezi a mészváz korrózióját. Mivel a klímaelemek értékeinek átlaga akár évenként csökkenhet vagy növekedhet, a kifejlődő házak mére- 
te a növekedési periódusának (1-2 év) megfelelően kisebb vagy nagyobb lehet. A helyzetet tovább bonyolítja az a tény, hogy azonos időpontban „startoló” példányok mérete ab ovo szórást mutat. $A$ tapasztalt variabilitás tehát részben örökletes, részben pedig ökológiai gyökerü. Az elmondottakból kitünik, hogy ideális eredményhez csak akkor juthatunk, ha csak $E 1$ és $E$ 2 létállapotú egyedeket gyüjünk a mintánkba. Ezt az igényt a megkívánt mintaelemszámmal összeegyeztetni még sziszifuszi munkával sem mindig lehet. Ráadásul minél nagyobb területről gyűjtjük be a mintát, a különböző klimatikus adottságú biotópokból származó egyedek összekeveredésének valószínűsége annál nagyobb lesz. A posteriori megoldás - igényünket kiterjesztjük E 3, E 4 létállapotú példányokra is (Sólymos \& Doмокоs 1999). Ezt annál is inkább megtehetjük, hiszen az irodalmi makroklímaelemek (hőmérséklet, páratartalom stb.) több évtizedes megfigyelés alapján nyert átlagok.

A nyolc biotóp közül csupán ötben sikerült a kiértékelés szempontjából praktikus 100 mintaelemet gyűjteni. A legkisebb minták csupán 50 elemesek, de így is 20-al meghaladják a minimális mintaelemszámot (DoMOKOS 1982).

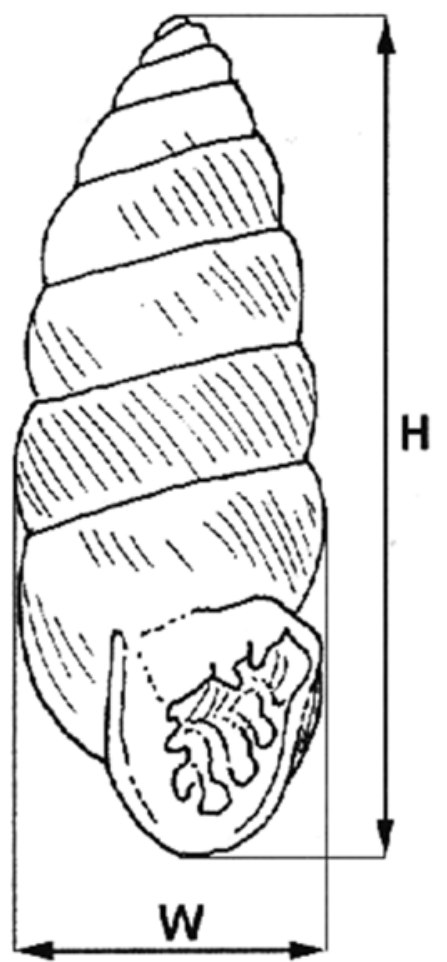

3. ábra: $A$ Granaria frumentum mért paraméterei: $H=$ magasság, $W=$ szélesség (Sólymos et al. 2002)

Fig. 3.: The shell of the Granaria frumentum with the measured parameters.

$H=$ height, $W=$ width (Sólymos et al. 2002)
A magasság $(H)$ és szélesség $(W)$ értékek mérését tolómérővel végeztük $0,1 \mathrm{~mm}$ alatti pontossággal; ép, kitüremlett szájadékszegéllyel rendelkező egyedeken (3. ábra). A szájadék tolóméter alsó mozgó pofájával érintkező pontja, és a felső pofa ház csúcsával érintkező pontján át fektetett egyenes csak látszólag merőleges a pofákra. Ennek oka az érintkező pontokon fellépő súrlódás, amely megakadályozza a ház kicsúszását, annak nem merőleges állapotában is. A mérést követő feldolgozás után megrajzoltuk a gyakorisági görbéket, amelyek abszcisszáján a hagyományokhoz híven $0,3(\mathrm{H})$, illetve $0,1(\mathrm{~W}, \mathrm{H} / \mathrm{W}$ ) az osztályköz (DoMOKos 1982). Minden esetben sort kerítettünk a nyúltság $(H / W)$ kiszámítására is.

A mérés során nyert paraméterekböl meghatározott morfometriai jellemzőket és az azok segítségével meghatározott „alakhőmérsékleteket” (PT, PT1), valamint az irodalomból származó júliusi középhőmérsékletet (JMT) az 1. táblázatban foglaltuk össze. Egyes mintákhoz rendelhető „alakhőmérsékleteket” (PT) a magasság $(\mathrm{H})$ és szélesség $(\mathrm{W})$ móduszok $(\mathrm{MO})$, illetve az átlagmagasságok (AM) segítségével határoztuk meg. A PT értékét a Granaria frumentum MO értékeinek júliusi középhőmérséklet függését bemutató grafikonról (4. ábra) olvastuk le (DomoKos \& FüKÖH 1984 - Fig.4.), illetve az átlagmagasság ismeretében számítottuk ki SótYmos \& SÜMEGI 1999 regressziós egyenest leíró egyenletéből [PT1 = $(\mathrm{AM}-2,1747) / 0,2824]$. Ez utóbbi úton kapott értéket megkülönböztetésül jelöltük $\mathrm{PT1}$-el. A regressziós egyenlethez szükséges adatokat a Szársomlyón, az Oltárkőn és a Kereszteskőn gyűjtött Granaria frumentum magasság $(\mathrm{H})$ adatainak számtani átlagából és az irodalomból átvett júliusi középhőmérséklet adatokból (MARosı \& Somogyı 1990, Pécsı et. al. 1989) nyerte Sólymos Péter és Sümegi Pál. Szeretnénk hangsúlyozni, hogy a 4. ábra abcisszáján látható mikroklíma értékekkel paralel változnak, az un. lokális makroklíma értékek, amelyek az eltérő felvételi helyből és évből adódóan eltérhetnek a regionális makroklímától.

\section{Eredmények}

\section{A. Eloszlásgörbék}

A tolóméteres mérés jó reprodukálhatóságát mutatja, hogy az 1987-es balatonszárszói minta (4. számú gyűjtőhely) elemeinek ismételt lemérése után kapott frekvencia értékek viszonylag jó megegyezést mutatnak. Az alap és kontroll mérés egyes paramétereinek átlaga között csupán - 0,02 $(\mathrm{H}),-0,01(\mathrm{~W})$ $\mathrm{mm}$ illetve $0,00(\mathrm{H} / \mathrm{W})$ eltérés $(0,1 \%$ alatti) mutatkozott (5. és 6. ábra, 1. táblázat), annak ellenére, hogy a két mérés során az egyes osztályközbe tartozó $\mathrm{H}-\mathrm{W}-\mathrm{H} / \mathrm{W}$ értékek akár 3-6-7\%-al is eltérhetnek egymástól. A kismértékü méretcsökkenés - véleményünk szerint - a mérés során bekövetkező csekélyke kopással hozható összefüggésbe. A magasság $(H)$ értékek egycsúcsú enyhén jobbra ferde; a szélesség (W) egycsúcsú, megközelítően szimmetrikus; a nyúltság $(H / W)$ az alap sorozatnál enyhén balra, a kontrollnál pedig jobbra ferde eloszlást mutat. 


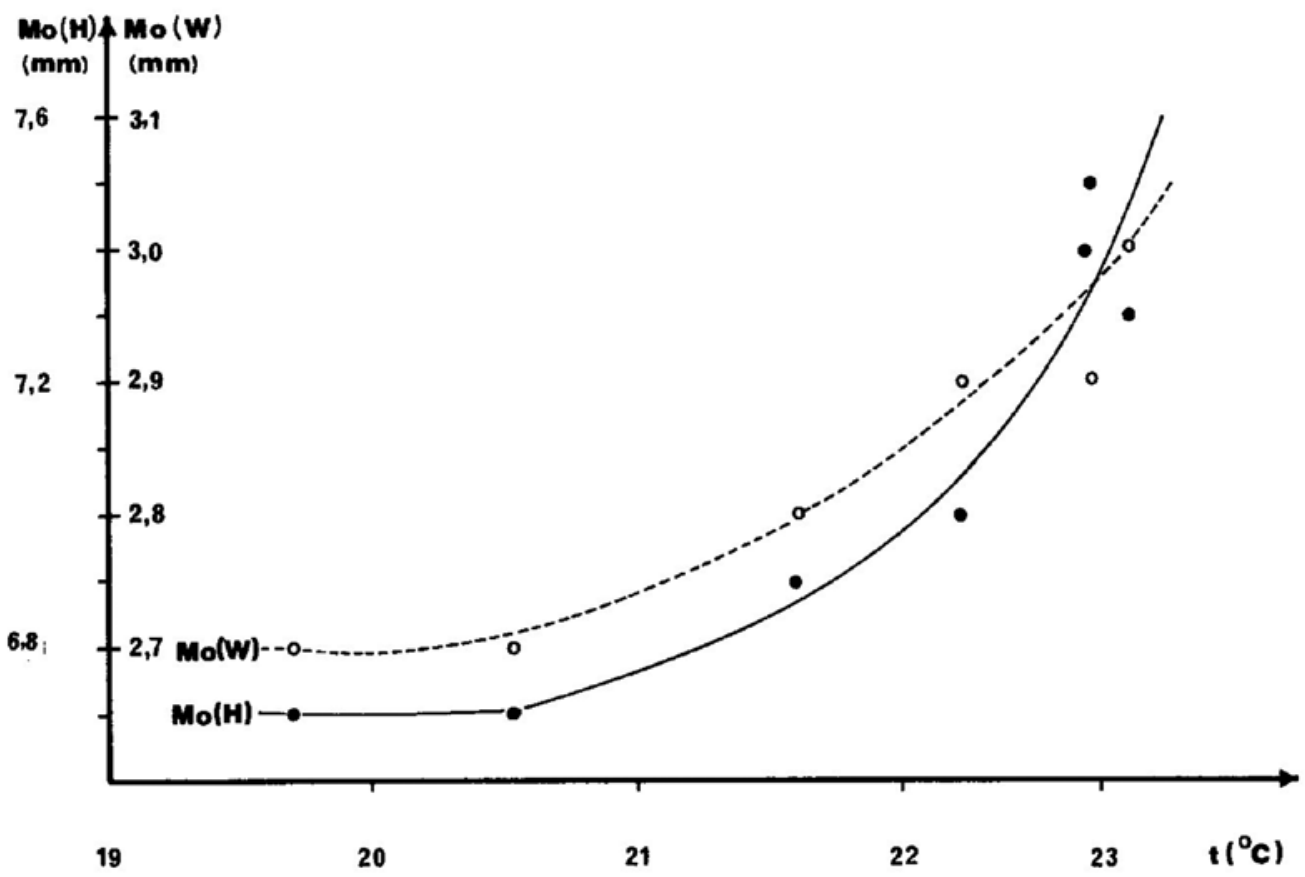

4. ábra: A Granaria frumentum móduszainak (MO) júliusi középhömérséklet függése (Doмокоs \& FüKöH 1984)

Fig. 4.: Relationship between modes (MO) of the Granaria frumentum and July mean temperature

(Dомокоs \& FÜкӧн 1984)

A következő két ábrán (7. és 8.) egy tihanyi (1.) és egy szárszói (4.) erdei minta, valamint négy gyepminta magasság $(H)$ értékeinek eloszlása látható.

Átnézve az erdős és a gyepes biotópok magasság értékeinek eloszlását, megállapítható, hogy a gyepek frekvencia görbéi aszimmetrikusabbak, illetve a normális eloszlástól bal oldali törésük különbözteti meg. A szárszói gyep (5. minta) jobbra ferde eloszlása és baloldali törése a legszembetünőbb a gyepek között. Érdekes a tihanyi (1.) és a szárszói (4.) minta viszonylag jó kongruenciája (7. ábra).

Legkisebb értékeket a szárszói homokbánya feletti, Balatonhoz legközelebb fekvő gyepminta mutatja, ezt követi a szóládi, kötcsei és az almahegyi gyep. A szárszói gyepminta alacsonyabb gyakorisági értékei feltehetően a Balaton közelségével, nagy víztömegének kiegyenlítő hatásával magyarázható (Dомокоs \& KovÁCS 1982, TüSKÉs 2007). Érdekes, hogy a frekvencia görbék eltolódásának sorrendje nem felel meg a Balatontól való távolság növekedésének a sorrendjével. Az almahegyi minta frekvencia görbéje, a bányafal feletti pozíciójából következően, melegebb mikroklímája miatt tolódhat el a magasabb értékek felé. Az almahegyi és a kötcsei mintasor átlagmagassága 0,1 ; MO-a és ME-ja 0,2 mm-rel; szórása csupán 0,07-al tér el egymástól.

A következő két ábra (9. és 10.) három, különböző évben $(1980,1985,1987)$ gyűjtött szárszói minta magasságának $(H)$, szélességének $(W)$ és nyúltságának $(H / W)$ frekvenciagörbéit szemlélteti. Az elöbb sorolt 2., 3. ,4. minta ugyanabban az akácosban került begyüjtésre.
Ami első pillanatra szembetűnik: a magasság $(\mathrm{H})$ és szélesség (W) eloszlásgörbéi az évek múlásával a kisebb értékek felé tolódnak el, azaz az erdei mikroklímában az évek előrehaladtával csökkenő júliusi átlaghőmérséklet valószínüsíthető. $A$ nyúltság $(H / W)$ eloszlása - az 1985-ös évi 2. minta okán - a fenti regulától eltér. A 2. minta eloszlásgörbéjénél, a többihez képest, hegyesebb profil figyelhető meg. Ez a kiugró viselkedés a kisebb - 100 helyett 80 - mintaszámmal hozható összefüggésbe (!)

Meglepő, hogy egymástól légvonalban megközelítően 10 km-re fekvő, két különböző időpontban gyűjtött, különböző expozíciójú tihanyi (1. minta: 1982, É-i kitettség) és szárszói minta (4. minta: 1987,) bizonyos szélesség $(W)$ és nyúltság $(H / W)$ osztályközeinek értékei milyen jól megközelítik egymást. Csupán a szárszói minta frekvencia értékei mutatnak némi eltolódást a nagyobb értékek irányába (11. ábra).

\section{B. Morfológia a statisztikai jellemzők tükrében és a kalkulált héj morfo-hőmérsékletek}

A statisztikai jellemzők és az alakhőmérsékletek meghatározása után, a makrohőmérsékleti adatok beszerzését követően készült el az 1. táblázat.

$A z$ 1. táblázatot megtekintve látható, hogy a centrális tendencia értékek ( $\mathrm{AM}, \mathrm{MO}, \mathrm{ME})$ alapján a gyakorisági függvények csupán kismértékű balra és jobbra eloszlást mutatnak. A szórás értékek között lényeges különbség nem észlelhető, még a kisebb mintaelemszámok esetében sem. 
A vizsgált régióban a magasság értékek $(H)$ 5,8 és 8,4 $\mathrm{mm}$, a szélesség $(W)$ értékek 2,3 és $3,1 \mathrm{~mm}$, a nyúltságok $(H / W)$ pedig 2,1 és 3,1 közötti értékeket vesznek fel.

A tihanyi és az 1987. évi szárszói erdei minta statisztikai jellemzőiben csupán a századokban mutatkozik eltérés. A négy gyepminta átlagmagasság és nyúltság értékeiben - kivéve az almahegyit - dél felé haladva növekvő tendencia tapasztalható. Az előbbi észleletekkel szemben, a nyúltságban nem jelentkezik az almahegyi minta devianciája (7. és 8. ábra).
Visszatérve a három szárszói erdei minta (2., 3., 4.) paramétereinek diszkussziójához, megállapíthatjuk, hogy az évek múlásával a paraméterek statisztikus jellemzői csökkenést mutatnak. Ennek a klímaváltozás, vagy a véletlen lehet az oka. Ez utóbbinak ellentmond a szélesség és nyúltság mérőszámaiban megmutatkozó néhány százados, a magasság értékekben megmutatkozó $0.21 \mathrm{~mm}$-es különbség.

1. táblázat: Granaria frumentum populációk morfometriai jellemzői és a júliusi alakhőmérsékletek (PT, PT1)

Table 1.: Size distribution characteristics of the measured Granaria frumentum populations and estimated July mean temperatures (PT, PT1) with shell morpho-thermometer method

N: mintaelemszám/number of cases, $H$ : házmagasság/height, W: szélesség/width, H/W: nyúltség/elongation, AM: számtani átlag/ arithmetic mean, MO: módusz/mode, ME: medián/median, SD: szórás/standard deviation, Min: minimum/ minimum value, Max: maximum/ maximum value, $d$ : mérésterjedelem/range of measurement PT according to FüKÖH \& DOMOKOs 1984 szerint, PT1: according to SólyMOS \& SÜMEGI 1999 szerint

\begin{tabular}{|c|c|c|c|c|c|c|c|c|c|c|c|c|}
\hline \multirow[t]{2}{*}{ Gyüjtőhely } & \multirow[t]{2}{*}{ Paraméterek } & \multicolumn{8}{|c|}{ Statisztikai jellemzők } & \multicolumn{3}{|c|}{$\begin{array}{c}\text { Hőmérsékletek } \\
\left({ }^{\circ} \mathrm{C}\right)\end{array}$} \\
\hline & & $\mathrm{N}$ & AM & $\mathrm{MO}$ & $\mathrm{ME}$ & SD & Min & Max & $\mathrm{d}$ & PT & PT1 & $\mathrm{JMT}$ \\
\hline \multirow{3}{*}{$\begin{array}{l}\text { 1. Tihany, Ciprián-f. } \\
\text { (1982) }\end{array}$} & $\mathrm{H}(\mathrm{mm})$ & \multirow{3}{*}{100} & 6.84 & 6.8 & 6.8 & 0.45 & 6.0 & 8.4 & 2.4 & 21.2 & 16.5 & \multirow{31}{*}{$\begin{array}{l}20- \\
21\end{array}$} \\
\hline & $\mathrm{W}(\mathrm{mm})$ & & 2.74 & 2.8 & 2.8 & 0.09 & 2.6 & 3.0 & 0.4 & 21.6 & & \\
\hline & $\mathrm{H} / \mathrm{W}$ & & 2.44 & 2.5 & 2.4 & 0.15 & 2.2 & 2.8 & 0.6 & & & \\
\hline \multirow{3}{*}{$\begin{array}{l}\text { 2. B. szárszó, } \\
\text { magaspart, } \\
\text { akácos }(1980)\end{array}$} & $\mathrm{H}(\mathrm{mm})$ & \multirow{3}{*}{80} & 7.19 & 7.3 & 7.2 & 0.38 & 6.4 & 8.4 & 2.0 & 22.6 & 17.7 & \\
\hline & $\mathrm{W}(\mathrm{mm})$ & & 2.82 & 2.8 & 2.8 & 0.09 & 2.6 & 3.0 & 0.4 & 21.6 & & \\
\hline & $\mathrm{H} / \mathrm{W}$ & & 2.51 & 2.5 & 2.5 & 0.12 & 2.3 & 2.8 & 0.5 & & & \\
\hline \multirow{3}{*}{$\begin{array}{l}\text { 3. B. szárszó, } \\
\text { magaspart, } \\
\text { akácos (1985) }\end{array}$} & $\mathrm{H}(\mathrm{mm})$ & \multirow{3}{*}{100} & 6.98 & 6.8 & 7.0 & 0.33 & 6.2 & 8.0 & 1.2 & 21.2 & 17.0 & \\
\hline & $\mathrm{W}(\mathrm{mm})$ & & 2.81 & 2.8 & 2.8 & 0.09 & 2.6 & 3.1 & 0.5 & 21.6 & & \\
\hline & $\mathrm{H} / \mathrm{W}$ & & 2.44 & 2.4 & 2.4 & 0.12 & 2.1 & 2.8 & 0.7 & & & \\
\hline \multirow{3}{*}{$\begin{array}{l}\text { 4. B. szárszó, } \\
\text { magaspart, } \\
\text { akácos (1987) }\end{array}$} & $\mathrm{H}(\mathrm{mm})$ & \multirow{3}{*}{100} & 6.83 & 6.8 & 6.8 & 0.40 & 6.0 & 7.9 & 1.9 & 21.2 & 16.4 & \\
\hline & $\mathrm{W}(\mathrm{mm})$ & & 2.77 & 2.8 & 2.8 & 0.09 & 2.6 & 3.0 & 0.4 & 21.6 & & \\
\hline & $\mathrm{H} / \mathrm{W}$ & & 2.42 & 2.4 & 2.4 & 0.14 & 2.1 & 2.8 & 0.7 & & & \\
\hline \multirow{3}{*}{$\begin{array}{c}\text { 2., 3. és } 4 \text {. összevont } \\
\text { minta }\end{array}$} & $\mathrm{H}(\mathrm{mm})$ & \multirow{3}{*}{280} & 6.98 & 6.8 & 7.0 & 0.39 & 6.0 & 8.4 & 2.4 & 21.2 & 17.0 & \\
\hline & $W(\mathrm{~mm})$ & & 2.80 & 2.8 & 2.8 & 0.09 & 2.6 & 3.1 & 0.5 & 21.6 & & \\
\hline & $\mathrm{H} / \mathrm{W}$ & & 2.45 & 2.4 & 2.45 & 0.13 & 2.1 & 2.8 & 0.7 & & & \\
\hline \multirow{3}{*}{$\begin{array}{l}\text { 2., 3. és 4. minta stat. } \\
\text { jellemzöinek átlaga }\end{array}$} & $\mathrm{H}(\mathrm{mm})$ & \multirow{3}{*}{3} & 7.00 & 6.9 & 7.0 & 0.37 & 6.0 & 8.4 & 2.4 & 21.7 & 17.1 & \\
\hline & $W(\mathrm{~mm})$ & & 2.80 & 2.8 & 2.8 & 0.09 & 2.6 & 3.1 & 0.5 & 21.6 & & \\
\hline & H/W & & 2.44 & 2.5 & 2.4 & 0.13 & 2.2 & 2.8 & 0.6 & & & \\
\hline \multirow{3}{*}{$\begin{array}{l}\text { 5. B. szárszó, } \\
\text { magaspart, } \\
\text { gyep (1987) }\end{array}$} & $\mathrm{H}(\mathrm{mm})$ & \multirow{3}{*}{100} & 6.74 & 6.7 & 6.7 & 0.46 & 5.8 & 8.1 & 2.3 & $19.6 !$ & 16.1 & \\
\hline & $\mathrm{W}(\mathrm{mm})$ & & 2.76 & 2.7 & 2.7 & 0.10 & 2.6 & 3.0 & 0.4 & $19.6 !$ & & \\
\hline & $\mathrm{H} / \mathrm{W}$ & & 2.38 & 2.5 & 2.4 & 0.14 & 2.1 & 2.7 & 0.6 & & & \\
\hline \multirow{3}{*}{$\begin{array}{l}\text { 6. B. szárszó, } \\
\text { Almahegy, } \\
\text { h. fal (1983) }\end{array}$} & $\mathrm{H}(\mathrm{mm})$ & \multirow{3}{*}{50} & 7.32 & 7.4 & 7.4 & 0.37 & 6.4 & 8.2 & 1.8 & 22,6 & 18.2 & \\
\hline & $\mathrm{W}(\mathrm{mm})$ & & 2.77 & 2.8 & 2.8 & 0.09 & 2.6 & 3.0 & 1.4 & 21.6 & & \\
\hline & $\mathrm{H} / \mathrm{W}$ & & 2.59 & 2.6 & 2.6 & 0.13 & 2.3 & 2.8 & 0.5 & & & \\
\hline \multirow{3}{*}{$\begin{array}{l}\text { 7. Szólád, domboldal, } \\
\text { (1983) }\end{array}$} & $\mathrm{H}(\mathrm{mm})$ & \multirow{3}{*}{50} & 7.00 & 7.0 & 7.0 & 0.43 & 6.3 & 8.1 & 1.8 & 22.1 & 17.1 & \\
\hline & $\mathrm{W}(\mathrm{mm})$ & & 2.79 & 2.8 & 2.8 & 0,11 & 2.3 & 3.0 & 0.7 & 21.6 & & \\
\hline & $\mathrm{H} / \mathrm{W}$ & & 2.46 & 2.5 & 2.45 & 0.17 & 2.2 & 3.1 & 0.9 & & & \\
\hline \multirow{3}{*}{$\begin{array}{l}\text { 8. Kötcse, domboldal } \\
\text { (1981) }\end{array}$} & $\mathrm{H}(\mathrm{mm})$ & \multirow{3}{*}{100} & 7.22 & 7.6 & 7.2 & 0.44 & 6.1 & 8.4 & 2.3 & 23.0 & 17.8 & \\
\hline & $\mathrm{W}(\mathrm{mm})$ & & 2.85 & 2.9 & 2.9 & 0.09 & 2.7 & 3.1 & 0.4 & 22.3 & & \\
\hline & $\mathrm{H} / \mathrm{W}$ & & 2.49 & 2.5 & 2.5 & 0.11 & 2.2 & 2.9 & 0.7 & & & \\
\hline 8. minta AM átlaga & $\mathrm{H}(\mathrm{mm})$ & 8 & 7.01 & 6.8 & & & & & & 21.2 & 17.1 & \\
\hline
\end{tabular}



KLÍMAFÜGGÉSE (GASTROPODA: CHONDRINIDAE)

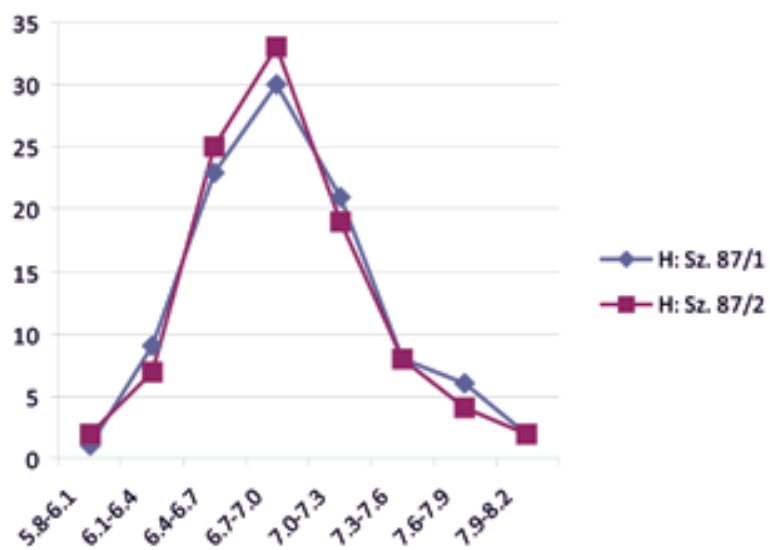

5. ábra: A 4. minta alap (négyzet) és kontroll (gyémánt) mérés során nyert magasság értékek gyakorisági eloszlása

Fig. 5.: The height $(H)$ distribution of the Granaria frumentum population from sample 4 . Square is base and diamond is control mensuration

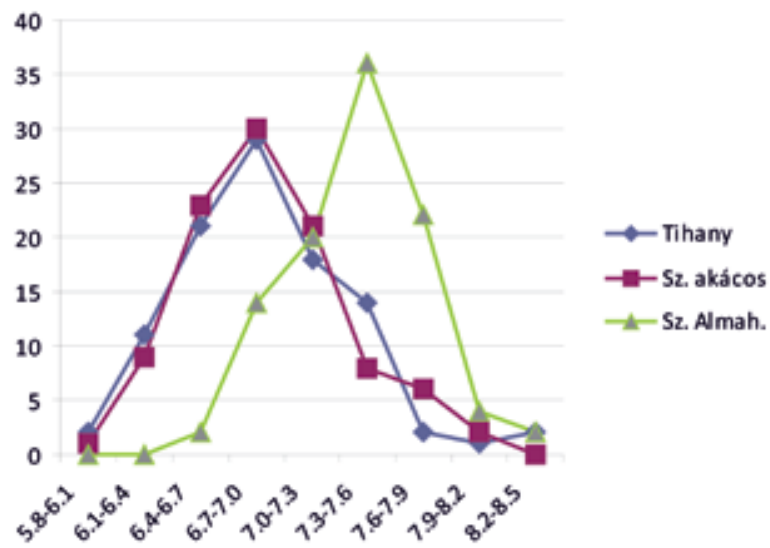

7. ábra: Különböző biotópokból származó Granaria frumentum minták magasság $(H)$ értékeinek frekvencia görbéi (gyémánt: 1. minta, négyzet: 4. minta, háromszög: 6. minta)

Fig. 7.: The height $(H)$ distribution of Granaria frumentum populations from different sampling sites (diamond: sample 1., square: sample 4., triangle: sample 6.)

A héj morfo-hőmérő módszerrekkel meghatározott hőmérsékleti értékek és a makrohőmérséklet összehasonlítása lehangoló, visszás eredményre vezet. A magasság MO-ból számítva 21,2-23,0, szélesség MO-ból számítva $21,6-22,3{ }^{\circ} \mathrm{C}$ között változnak a grafikus úton meghatározott PT értékek. Ezek az értékek a $20-21^{\circ} \mathrm{C}$ makroklímánál max. 2 osztályközzel $\left(2^{\circ} \mathrm{C}\right.$-al $)$ magasabbak. A regressziós egyenes egyenletéből számított PT1 értékek viszont $\sim 3^{\circ} \mathrm{C}$-al alacsonyabbak a $20-21{ }^{\circ} \mathrm{C}$ makroklíma (JMT) értéknél: $16,1-18,2^{\circ} \mathrm{C}$ közöttiek.

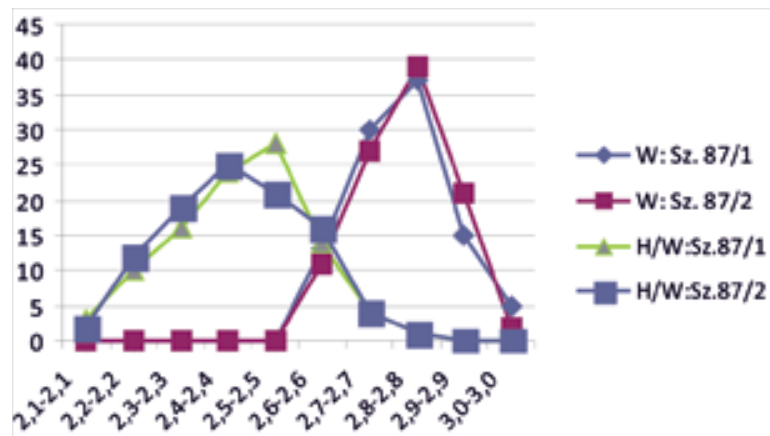

6. ábra: A 4. minta alap (/1) és kontroll (/2) mérése során nyert szélesség (W-gyémánt, négyzet,) és nyúltság $(H / W$ - háromszög, $x)$ frekvencia értékei

Fig. 6.: The height $(H)$ and elongation $(H / W)$

distribution of the Granaria frumentum population from sample 4. Diamond and square is base, triangle and $X$ is control mensuration

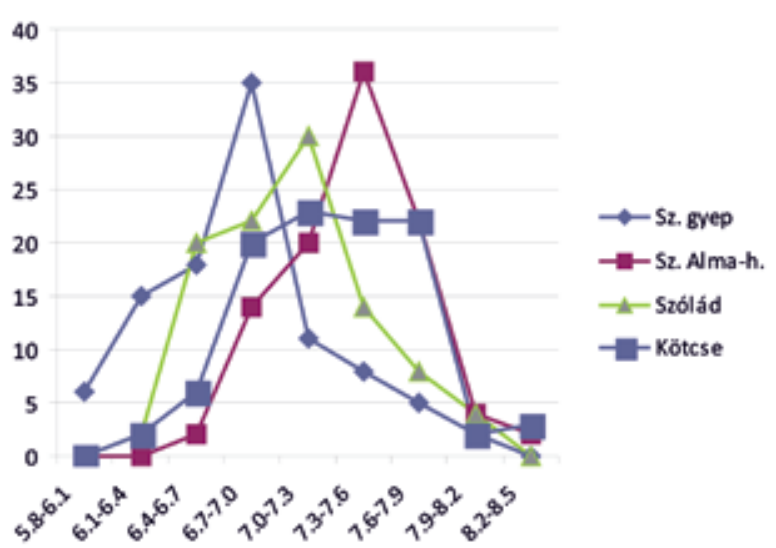

8. ábra: Különböző biotópokból származó Granaria frumentum minták szélesség $(H)$ értékeinek frekvencia görbéi (gyémánt: 5. minta, négyzet: 6. minta, háromszög: 7. minta, nagyobb négyzet: 8. minta)

Fig. 8.: The height $(H)$ distribution of Granaria frumentum populations from different sampling sites (diamond: sample 5., square: sample 6., triangle: sample 7., larger square: sample 8.)

\section{Összefoglalás}

Tihanyi-szárszói eredményeink rámutatnak arra, hogy a Granaria frumentum héjmorfológiája viszonylag kis térbeli léptékben (10-20 km) is jelentős variabilitást mutat, ami az élőhelyek helyi klímaelemeinek héjnövekedésre gyakorolt hatásának tudható be. A vizsgált gyepminták esetében, dél felé haladva, jól érzékelhető a héj paramétereinek enyhe növekedése 


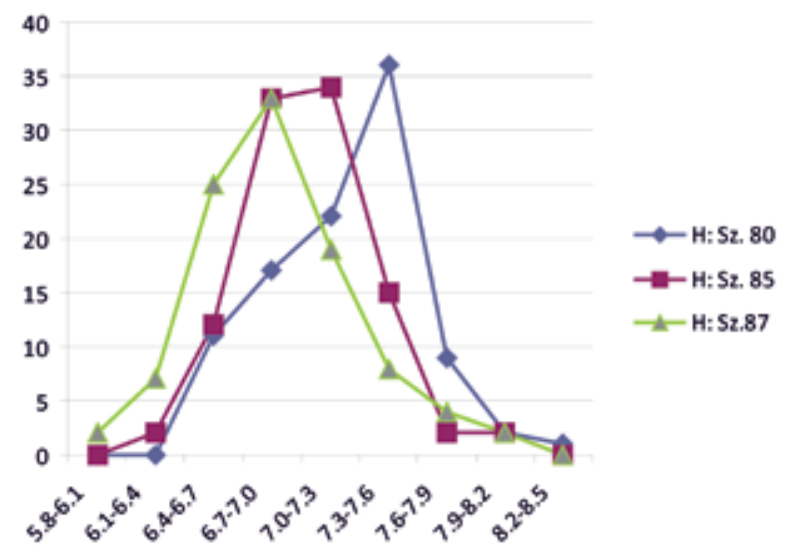

9. ábra: Granaria frumentum minták magasság $(H)$ értékeinek frekvencia görbéi (gyémánt: 2. minta, négyzet: 3. minta, háromszög:4. minta )

Fig. 9.: Distribution curves of height $(H)$ of Granaria frumentum (diamond: sample 2., square: sample 3 triangle: sample 4)

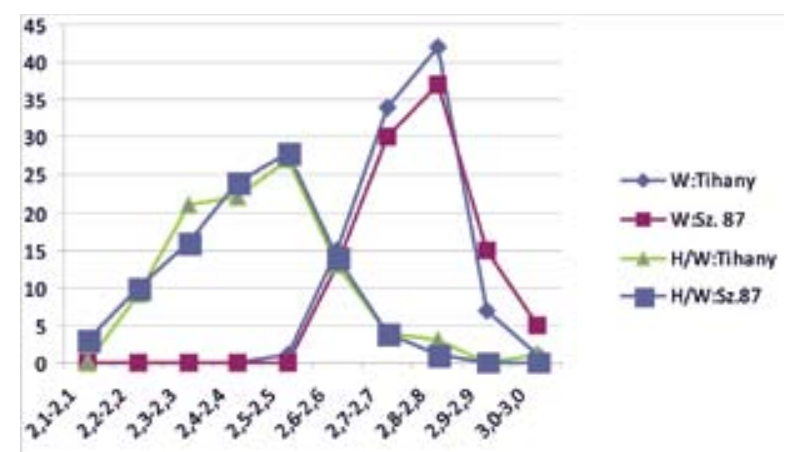

11. ábra: Granaria frumentum minták szélesség (W: gyémánt -1., négyzet - 4.minta) és nyúltság (H/W: háromszög - 1., x - 4. minta) értékeinek frekvencia görbéi

Fig. 11.: The width (W: diamond - sample 1., square - sample 4.) and elongation (H/W: triangle - sample 1., $x$ - sample 4.) curves of the Granaria frumentum populations

A héj morfo-hőmérővel meghatározott értékek makroklímával történő összevetése problémákat vet fel. A meghatározás metódusától függően +2 és $-3^{\circ} \mathrm{C}$ eltérés adódhat.

A tihanyi-szárszói biotópok $\mathrm{H}$ és $\mathrm{W}$ értékeire kapott 5,8-8,4 x 2,3-3,1 mm értékeket érdemes összehasonlítani néhány irodalmi adattal.

Soós 1943 klasszikus monográfiájában az előbbieknél nagyobb értéket ad meg (6-12 x 2,7-3,8 mm), ami érthető, hiszen a szerző a Kárpát-medencében gondolkodik, az ott található alfajokat is számításba veszi.

KERNEY et al. É- és Közép-Európa határozójában szereplő dimenziók: 6,5-8 x 2,7-3,0 mm. Ezek az általunk megadott értékeknél szükebbek. Igaz, zárójelben diplomatikusan megjegyzik: „oft erheblich größer”/ gyakran jelentékenyen nagyobb.

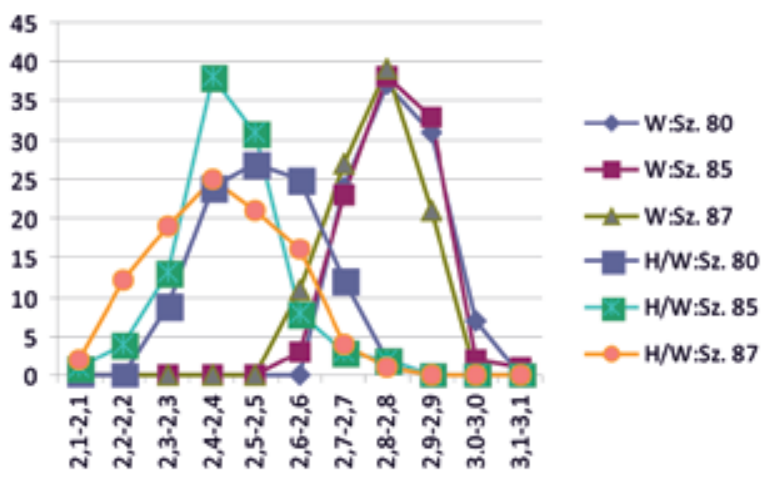

10. ábra: Granaria frumentum minták szélesség (W: gyémánt: 2., négyzet: 3. minta, háromszög: 4.minta) és nyúltság (H/W: x: 2 minta., csillag: 3. minta, kör: 4. minta) értékeinek frekvencia görbéi

Fig. 10.: The width (W: diamond-sample 2., square - sample 3., triaangle - sample 4.) and elongation (H/W: $x$ - sample 2., star- sample 3., circle - sample 4. ) curves of the Granaria frumentum populations

FeHÉR et al. (2010) a Közép-európai faj mérettartományát $6-8,9$ x 2,5-3,1 mm-ben adja meg. Ez utóbbi értékekhez esnek közelebb a szárszói adatok, ami evidens, hiszen Fehér Zoltán, Deli Tamás és Sólymos Péter a dimenziók megadásánál elvonatkoztattak az alfajoktól.

WeLter-SCHultes 2012 európai szárazföldi puhatestüekkel foglalkozó határozójában $\mathrm{H}$ és $\mathrm{W}$ értékre szúkebb intervallumokat ad meg: 6,5-8,0 x 2,7-3,0 $\mathrm{mm}$. Ez azért meglepő, mert a szerző által megadott értékek a Granaria frumentum Közép-Eeurópától DK-Bulgáriáig terjedő areájára vonatkoznak (WELTERSCHULTES 2012).

Sólymos \& Domokos 1999 a Balatontól 115 km-rel DDK-re fekvő, $20,8{ }^{\circ} \mathrm{C}$-os júliusi átlaghőmérsékletü praktice az általunk vizsgált terület makroklímájával megegyező $\left(20-21^{\circ} \mathrm{C}\right)$ - villányi Szársomlyó hegyen 1996-ban és 1997-ben gyűjtött 726 darab Granaria frumentum egyed házának statisztikáját készítette el. A nyert magasság $(\mathrm{H})$ Max adatai között több mintában $9 \mathrm{~mm}$ feletti érték fordult elő, de a csúcsot egy 10,2 mm-es magasságú héj tartja. $E$ helyen a szélességek (W) AM-je néhány mintában elérte a 3,3 mm-t, a Max-a pedig a 3,7 mm-t. A Szársomlyón tapasztalt dimenziók: 6,1-10,2 x 2,8-3,7 mm. Ezek az értékek, amelyek leginkább megközelítik Soós Lajosét (Soós 1943).

A Balaton környéki nyolc minta magasság átlagaiból számított 7,01 mm-es átlag (1. táblázat) 1,95 mm-rel kisebb - a megközelítően 115 km-rel délebbre fekvő - a Villányi-hegységi Szársomlyó (442 m) 9 mintája átlagának átlagától $(8,95 \mathrm{~mm})$. (Ez utóbbi értéket Sólymos \& DomoKos 1999 cikkének 1. táblázata alapján számítottunk ki.) A nyolc minta összevonásával kapott magasság MO-ból meghatározott alakhőmérséklet (PT) $21,2^{\circ} \mathrm{C}$, a regressziós egyenessel számított 8,95 mm-es AM-hez pedig $\sim 24^{\circ} \mathrm{C}$ júliusi átlaghőmérséklet tartozik. Ez utóbbi $\sim 3^{\circ} \mathrm{C}$ magasabb a regionális meteorológiai adatoknál 


\section{BALATON KÖRNYÉKI BIOTÓPOKBÓL (TIHANY, KÜLSÖ-SOMOGY) SZÁRMAZÓ GRANARIA FRUMENTUM (DRAPARNAUD, 1801) HÉJMORFOLÓGIÁJÁNAK KLIIMAFÜGGÉSE (GASTROPODA: CHONDRINIDAE)}

(MARosi \& Somogyı 1990), de jól jellemezheti az extrém déli kitettségü élőhely klímáját. A kitettségből fakadó klimatikus változatosság jelentős héjmorfometriai variabilitást eredményez, amely nagyban nehezíti a héjmorfológia és a makroklíma közötti kapcsolat általánosítását térben és időben (pl. klíma rekonstrukció). Az általánosításokhoz további összehasonlító vizsgálatokra van szükség.

\section{Köszönetnyilvánítás}

Suara Róbertnek az UTM koordináták revíziójáért; Puskás Mártának, az OMSZ könyvtárosának sokirányú segítségéért tartozunk köszönettel.

\section{Irodalom}

Agócsy P. 1961: Hazai csigafajaink elterjedését megszabó klímatényezők vizsgálata. - Állattani Közlemények, 52: 21-27. Budapest.

AGócsY P. 1962: A study of the climatic factors influencig the distribution of Mollusc species Hungary. - Annales Historico-Naturales Musei Nationalis Hungarici, 54: 473-481. Budapest.

AgócsY, P. 1966: Néhány éticsiga populáció vizsgálata. - Állattan Közlemények, 53: 13-19. Budapest.

AmBrózy P. et al. (eds) 2003: Magyarország éghajlati atlasza. Climate Atlas of Hungary. Országos Meteorológiai Szolgálat. Hungarian Meteorological Service. Budapest.

BÁBA, K. \& Domokos, T. 2002: Seasonal malacological ivestigations on the willow forest fauna (Csigáserdö) on the active flood plain of the Fekete-Körös River near Dénesmajor. - NEV Malakologischen Gesselschaft, 10: 31-42. Rankweil.

Domokos, T. 1982: Morphometrical study of the chronocline of Granaria frumentum (Draparnaud, 1801) (Gastropoda: Chondrinidae). Miscellanea Zoologica Hungarica, 1: 45-51.Budapest.

Doмокоs T. 1982-83: Shell morphometry of Chondrula tridens (O.F. Müller) from the surroundings of Békéscsaba (Gastropoda, Enidae). - Soosiana, 10-11: 125-134. (in English with Hungarian abstract). Baja.

Domokos T. 1985: A Horváth-likból (Uppony) elökerült holocén Granaria frumentum (Draparnaud) morfológiai vizsgálata és kora. Malakológiai Tájékoztató, 5: 9-13. Gyöngyös.

Doмокоs T. 1987: A klíma hatása a Helicigona banatica csigafaj házának alaki jellemzőire egyik alföldi előfordulása helyén. - Alföldi Tanulmányok, XI: 45-60. Békéscsaba.

Domokos T. 1992: A klíma hatása a Helicigona banatica csigafaj házának morfológiájára Makó-Landori-erdőben. - Fol. Hist.-nat. Mus. Matr., 17: 189-198. Gyöngyös.

Doмокоs T. 1995: A Gastropodák létállapotáról, a létállapot osztályozása a fenomenológia szintjén. - Malakológiai Tájékoztató, 14: 79-82. Gyöngyös.

Domokos T. 2001: Data on the shell morphology of the Chilostoma banatica (E. A. Rossmässler, 1838) and its climate dependence in the Sitka Forest (Békés County, Gyulavári) (Mollusca, Gastropoda). Adatok a Chilostoma banatica (E. A. Rossmässler, 1838) Sitkai-erdőböl (Békés megye, Gyulavári) gyüjtött egyedeinek héjmorfológiájához és annak klímafüggéséhez (Mollusca, Gastropoda) - Soosiana, 29:11-26. Nagykovácsi.

Domoкоs T. 2002: Cochlodina laminata (Montagu, 1803) létállapotának klíma okozta változásairól békéscsabai (Békés megye) megfigyelések alapján. - Malakológiai Tájékoztató, 20: 35-46. Gyöngyös.

Domokos T. És FüKöH L. 1984: A Granaria frumentum (Draparnaud, 1801) héjmorfológiája a klímatológiai vizsgálatok tükrében. Fol.Hist.-nat.Mus.Matr., 9:91-107. Gyöngyös

Dомокоs, T. \& FüкÖH, L. 1986: Relationship between microclimate and the shellmorphometry of Granaria frumentum (Draparnaud, 1801) (Gastropoda, Chondrinidae) - Proceedings of the 8 th International Malacological Congress, Budapest, 69-74 pp.
Doмокоs T., És KovÁcs, Gy. 1982: A balatoni Fekete-part és környékének malakofaunája. - Állattani Közlemények, 69: 61-68. Budapest.

Domokos T., LENNERT J. És Sólymos P. 2004: Száraz holtág malakológiai mikroklímatológiai vizsgálata a Sarkad-Remetei-erdőben (Békés megye), és a Hygromia kovacsi elöfordulási körülményei. - Malakológiai Tájékoztató, 22: 87-95. Gyöngyös

DöVÉnyı Z., Mosolygó L., Rakonczal J. És Tóth J. 1977: Természeti és antropogén folyamatok földrajzi vizsgálata a kígyósi puszta területen. - Békés megyei Természetvédelmi Évkönyv, 2: 43-72. Békéscsaba.

Fehér, Z., Deli, T. \& Sólymos, P. 2010: Revision of Granaria frumentum (Draparnaud, 1801) (Mollusca, Gastropoda, Chondrinidae) subspecies occurring in the eastern part of the species range. Journal of Conchology, 40: 201-217.London.

FüKöH L. 1980: Adatok az Upponyi-szoros csigafaunájához. - Fol. Hist.-nat. Mus. Matr. 6: 137-145. Gyöngyös

Kemencei, Z., Farkas, R., Páll-Gergely, B., Vilisics, F., Nagy, A. Hornung, E. \& Sólymos, P. 2014: Microhabitat associations of land snails in forested dolinas: implications for coarse filter conservation. - Community Ecology. in press.

Kerney, M. P., Cameron, R. A. D. \& Jungbluth, J. H. 1983: Die Landschnecken Nord- und Mitteleuropas. Verlag Paul Parey.1384 p. Hamburg und Berlin.

LAIS, R. 1925: Dr. Hans Kauffmann's hinterlassene Schneckensammlung. Ein Beitrag zur Kenntnis der Schneckenfauna Südbadens und ihrer Beziehungen zum Klima. - Berichte der Naturforschenden Gesellschaft zu Freiburg i. Br. 25:1-74. Naumburg.

LAIS, R. 1926: Klima und Schneckenhaus. Aus Natur und Museum. Frankfurt am Main.

MARosı S. És Somogyı S. (eds.) 1990: Magyarország kistájainak katasztere. I-II. MTA Földrajztudományi Kutató Intézet. 1023 p. Budapest.

NAGY, A. \& Sólymos, P. 2002: Relationship between microclimate and Orthoptera assemblages in different exposures of a dolina. Articulata, 17(1): 73-84. Rednitzhembuch.

NAGY L. 1992: Microclimate types in the southern Bükk. - Abstracta Botanica, 16 (2): 87-90. Budapest.

OMSZ: Időjárás havijelentés Magyarországról 1974 és 1985 közötti számai. - OMSZ Budapest

PÉcsı M. et al. (eds.) 1989: Magyarország nemzeti atlasza. Kartográfiai Vállalat. Budapest.

PINTÉR L. És SuARA R. 2004: Magyarországi puhatestűek katalógusa hazai malakológusok gyűjtései alapján [Catalogue of the Hungarian molluscs based on the collectings of Hungarian malacologists]. - in: Fehér, Z.\& Gubányi, A. (eds.): A magyarországi puhatestüek elterjedése [Distribution of the Hungarian molluscs] II. Magyar Természettudományi Múzeum, 547 pp. Budapest.

ROTARIDESz M. 1927: A variabilitásról és tanulmányozásának módszereiröl. - Állattani Közlemények, 24: 143-163. Budapest. 
RotARIDESz M. 1931: A lösz csigafaunája összevetve a mai faunával, különös tekintettel a Szeged vidéki löszökre. - A Szegedi Alföldkutató Bizottság Könyvtára. VI. szakosztály. Állattani Közlemények, 8: 1-180. Szeged.

Sólymos, P. 1996: Ecological and biogegraphical investigation of the recent mollusc fauna of Szársomlyó (S Hungary), southern side. - Malakológiai Tájékoztató, 15: 61-67. Gyöngyös. (in English with Hungarian abstract)

Sólymos, P. \& Domokos, T. 1999: A possible connection between macroclimate and shell morphometry of Granaria frumentum (Draparnaud, 1801) (Gastropoda: Chondrinidae). - Malakológiai Tájékoztató, 17: 75-82.Gyöngyös.

Sólymos, P., Farkas, R., Kemencei, Z., Páll-Gergely, B., Vilisics, F., Nagy, A., Kisfali, M. \& Hornung, E. 2009: Microhabitat scale survey of land snails in dolinas of the Alsó-hegy, Aggtelek National Park, Hungary. - Mollusca, 27(2): 167-171. Dresden.

SólYMOS P. \& NAGYA. 1997: The recent mollusc fauna of the Szársomlyó (S Hungary): spatial pattern and microclimate. - Malakológiai Tájékoztató, 16: 35-42. Gyöngyös.

Sólymos P. És SüMEGI P. 1999: The shell morpho-thermometer method and its application in palaeoclimatic reconstruction. - Annales Universitatis Scientiarum Budapestinensis, Sectio Geologica, 32: 137-148. Budapest.
Sólymos P., Sümegı P. És Domokos T. 2002: A héj morpho-hömérö módszer és alkalmazásai a paleoökológiában. - Földtani Közlöny, 132/különszám, 257-263. Budapest.

Soós L. 1943: A Kárpát-medence Mollusca-faunája. - In: Magyarország természetrajza, I. Állattani rész. Magyar Tudományos Akadémia, 478 pp. (+XXX). Budapest.

SüMEGI P. 1989: A Hajdúság felső pleisztocén fejlődéstörténete finomrétegtani (őslénytani, szedimentológiai, geokémiai) vizsgálatok alapján. - Doktori értekezés, Debrecen, Kézirat, 75 pp.

SüMEGI P. 1996: Az ÉK-magyarországi löszterületek összehasonlító őskörnyezeti rekonstrukciója és rétegtani értékelése. - Kandidátusi értekezés, KLTE, Debrecen, Kézirat, $120 \mathrm{pp}$.

TüskÉs T. 2007: Természeti környezet. - in: MAURER., T. (ed.): Szántód községtörténet. Szántód Község Önkormányzata, 18-26 pp. Szántód.

Welter-Schultes, F. 2012: European non-marine molluscs, a guid for species identification. Planet Poster Editions. 679 pp+ Q 1-70. Göttingen. 